\title{
Editorial: Volume 34 Issue 1
}

We are pleased to present the latest issue of AJET. As our first issue for 2018 it is timely to provide some bibliometrics on the recent performance of the journal. The bibliometric data in this editorial provide readers with information about the journal's publication, review and article access statistics, the articles attracting the most interest over the past year and the citation performance of the journal. The data has been summarised in a series of tables below along with explanatory notes and brief commentary.

As can be seen within Table 1, AJET has continued to publish 6 issues in 2017, two of which were dedicated to specific topic areas. In contrast to previous years the number of articles in the regular issues were increased from 8 to 11. This was done because of the increasing pressure of AJET's commitment to early release and the continued strong volume and quality of submissions.

The number of downloads per article has risen considerably, looking at the comparable timeframes for issues published from 2014 to 2016. For 2016/17 it seems that there has been a shift towards abstracts, with abstract downloads trending higher. Compared to the access figures from last year, there are about 7,000 additional full articles downloads per year, amounting to an average of about 150 new downloads per article per year. These figures show that AJET is attracting strong interest from its readership.

Table 1

AJET Publication Summary

\begin{tabular}{lrrr}
\hline & 2015 & 2016 & 2017 \\
\hline Issues published & 6 & 6 & 6 \\
Articles published & 46 & 45 & 57 \\
Editorials published & 6 & 6 & 6 \\
Article and editorial downloads (to 28/02/2018) & & & \\
$\quad$ Abstracts & 36124 & 32610 & 12287 \\
$\quad$ Full articles & 31327 & 23764 & \\
\hline
\end{tabular}

Table 2 shows the most downloaded articles per issue published in 2017. Readers will appreciate that the download numbers only provide indications of popularity and cannot be compared across issues that closely after publication. Time will tell which articles will attract sustained attention.

Table 2

Top 2017 AJET Articles per Issue by Full Article Downloads to 28/02/2018

\begin{tabular}{|c|c|c|c|}
\hline Issue & Article & Authors & Downloads \\
\hline $\begin{array}{l}\text { Vol 33, } \\
\text { No } 1\end{array}$ & $\begin{array}{l}\text { The important elements of LMS design that } \\
\text { affect user engagement with e-learning tools } \\
\text { within LMSs in the higher education sector }\end{array}$ & N Zanjani & 366 \\
\hline $\begin{array}{l}\text { Vol 33, } \\
\text { No } 2\end{array}$ & $\begin{array}{l}\text { Investigating the effect of learning styles in a } \\
\text { blended e-learning system: An extension of the } \\
\text { technology acceptance model (TAM) }\end{array}$ & $\begin{array}{l}\text { A Al-Azawei, P Parslow, K } \\
\text { Lundqvist }\end{array}$ & 292 \\
\hline $\begin{array}{l}\text { Vol 33, } \\
\text { No } 3\end{array}$ & $\begin{array}{l}\text { TPACK updated to measure pre-service } \\
\text { teachers' twenty-first century skills }\end{array}$ & $\begin{array}{l}\text { T Valtonen, E Sointu, J } \\
\text { Kukkonen, S Kontkanen, MC } \\
\text { Lambert, K Mäkitalo-Siegl }\end{array}$ & 330 \\
\hline $\begin{array}{l}\text { Vol 33, } \\
\text { No } 4\end{array}$ & $\begin{array}{l}\text { Reading an augmented reality book: An } \\
\text { exploration of learners' cognitive load, } \\
\text { motivation, and attitudes }\end{array}$ & KH Cheng & 380 \\
\hline $\begin{array}{l}\text { Vol 33, } \\
\text { No } 5\end{array}$ & $\begin{array}{l}\text { University students’ perceptions of social } \\
\text { networking sites (SNSs) in their educational } \\
\text { experiences at a regional Australian university }\end{array}$ & $\begin{array}{l}\text { C Sadowski, M Pediaditis, R } \\
\text { Townsend }\end{array}$ & 1128 \\
\hline $\begin{array}{l}\text { Vol 33, } \\
\text { No } 6\end{array}$ & $\begin{array}{l}\text { Key themes in mobile learning: Prospects for } \\
\text { learner-generated learning through AR and VR }\end{array}$ & $\begin{array}{l}\text { C Aguayo, T Cochrane, V } \\
\text { Narayan }\end{array}$ & 264 \\
\hline
\end{tabular}


Table 3 shows a comparison of the number of submissions and acceptance rates for articles submitted in 2015, 2016 and 2017. In 2017 the number of submissions increased again and surpassed the 2015/16 numbers. The percentage of submissions deemed of sufficient quality to be passed on for full peer review has declined compared to the 2015/16 period.

Table 3

AJET Submission and Review Statistics based on submissions per year

\begin{tabular}{|c|c|c|c|}
\hline AJET Submissions and Reviews & 2015 & 2016 & 2017 \\
\hline Total submissions & 427 & 464 & 529 \\
\hline $\begin{array}{l}\text { Declined at editorial screening (percentage of total } \\
\text { submissions) }\end{array}$ & 277 (65\%) & $298(64 \%)$ & $386(73 \%)$ \\
\hline Peer reviewed (percentage of total submissions) & $150(35 \%)$ & $166(36 \%)$ & $143(27 \%)$ \\
\hline $\begin{array}{l}\text { Declined at peer review (percentage of peer } \\
\text { reviewed) }\end{array}$ & 82 (55\%) & $99(60 \%)$ & $71 *$ \\
\hline Accepted (percentage of peer reviewed) & $68(45 \%)$ & $67(40 \%)$ & $38 *$ \\
\hline $\begin{array}{l}\text { Declined (either at editorial screening or following } \\
\text { peer review, percentage of total submissions) }\end{array}$ & $359(84 \%)$ & 397 (86\%) & \\
\hline Accepted (percentage of total submissions) & $68(16 \%)$ & $67(14 \%)$ & \\
\hline
\end{tabular}

* $\quad$ These are preliminary figures as 34 articles submitted in 2017 are still under review

Table 4 shows a summary of citation statistics from the Thomson Reuters Web of Science, Social Science Citation Index (SSCI) Journal Citation Reports (JCR), while Table 5 shows a summary of Google Scholar citation statistics. Readers interested in a detailed discussion of these statistics and how they are calculated are referred to the editorial within issue 30(3) of AJET. The AJET JCR factors for 2016 continue the positive trend shown in 2015. The two and five year impact factors are up and the citations have also increased.

Table 4

Thomson Reuters JCR SSCI Impact Factor

\begin{tabular}{lrrr}
\hline & 2014 & 2015 & 2016 \\
\hline Two Year Impact Factor & 0.648 & 0.798 & 0.853 \\
JCR SSCI total citations in the year & 537 & 705 & 939 \\
Impact factor without Journal self cites & 0.517 & 0.706 & 0.800 \\
JCR SSCI Five Year Impact Factor & 1.006 & 1.171 & 1.460 \\
JCR SSCI Two Year Impact factor ranking within & $131^{\text {st }}$ of 224 & $135^{\text {st }}$ of 231 & $151^{\text {st }}$ of 235 \\
Education \& Educational Research Category & & & \\
\hline
\end{tabular}

AJET's performance on the Google Scholar citation metrics has been fairly stable over the last years, with an h5-index of 32 and a h5-median of 44 in 2017. Google Scholar's ranking of Educational Technology journals places AJET $4^{\text {th }}$ internationally in 2017, showing an improvement in its positioning compared to other journals.

Table 5

Google Scholar Citation Metrics

\begin{tabular}{lccc}
\hline & June & June 2016 & June 2017 \\
\hline Google Scholar h5-index & 2015 & & \\
Google Scholar h5-median & 33 & 31 & 32 \\
Google Scholar h5-index ranking within Educational & 43 & 47 & 44 \\
Technology category & $8^{\text {th }}$ & $9^{\text {th }}$ & $4^{\text {th }}$ \\
\hline
\end{tabular}


Finally, Table 6 shows AJET's five most cited articles over the last five years, based on the Google Scholar h5-index.

Table 6

AJET's most cited articles over the last five years based the Google Scholar h5-index

\begin{tabular}{|c|c|c|c|}
\hline Article & Authors & Issue & Citations \\
\hline $\begin{array}{l}\text { Students' perceptions of using Facebook as an } \\
\text { interactive learning resource at university. }\end{array}$ & $\begin{array}{l}\text { C Irwin, L Ball, B } \\
\text { Desbrow, M Leveritt }\end{array}$ & $\begin{array}{l}\text { Vol 28, No 7, } \\
2012\end{array}$ & 212 \\
\hline $\begin{array}{l}\text { Schools going mobile: A study of the adoption } \\
\text { of mobile handheld technologies in Western } \\
\text { Australian independent schools. }\end{array}$ & $\begin{array}{l}\text { M Pegrum, G Oakley, } \\
\text { R Faulkner }\end{array}$ & $\begin{array}{l}\text { Vol 29, No 1, } \\
2013\end{array}$ & 148 \\
\hline $\begin{array}{l}\text { Challenging mobile learning discourse through } \\
\text { research: Student perceptions of Blackboard } \\
\text { Mobile Learn and iPads }\end{array}$ & $\begin{array}{l}\text { S Kinash, J Brand, T } \\
\text { Mathew }\end{array}$ & $\begin{array}{l}\text { Vol 28, No 4, } \\
2012\end{array}$ & 135 \\
\hline $\begin{array}{l}\text { The "third"-order barrier for technology- } \\
\text { integration instruction: Implications for teacher } \\
\text { education }\end{array}$ & CC Tsai, CS Chai & $\begin{array}{l}\text { Vol 28, No 6, } \\
2012\end{array}$ & 91 \\
\hline $\begin{array}{l}\text { Perceived convenience in an extended } \\
\text { technology acceptance model: Mobile } \\
\text { technology and English learning for college } \\
\text { students }\end{array}$ & $\begin{array}{l}\text { CC Chang, CF Yan, } \\
\text { JS Tseng }\end{array}$ & $\begin{array}{l}\text { Vol 28, No 5, } \\
2012\end{array}$ & 89 \\
\hline
\end{tabular}

\section{In this issue}

In this issue ten diverse articles range in contexts of focus from MOOCs to blended teaching, and from students' experience to professional development.

Brooker, Corrin, de Barba, Lodge and Kennedy report on a comparative study of two MOOCs and found that student motivation and participation predicted performance. However, the different purposes of the MOOCs meant that the students' demographics and motivations were different. They conclude by arguing that the design of MOOCs needs to be sensitive to the purpose of the course alongside a recognition of the motivations of its potential learners. Crosslin's paper offers another interesting perspective on the design of MOOCs. Crosslin explores the potential and design implications of self-regulated choices in a customisable learning pathway MOOC. A conclusion is that while learners desire greater personalisation there is still considerable more development required in our designs, as well as technology. Gómez-Rey, Barbera and Fernández-Navarro's article on identifying online instructors' roles offers a valuable extension to our thinking, particularly in light of Crosslin's exploration of learner self-regulation. It is perhaps of no surprise to educators who work in online courses that there is a greater need for the sharing of learning and working strategies. These three papers caution us that the focus of 'content creation' which seems to continue to dominate many institutional approaches to online courses and MOOCs needs to be balanced by equal effort in designing for learners' motivation, expectations of personalisation and their need for skill development in this new environment.

Savić, Segedinac, Milenković, Hrin and Segedinac report on their work in developing a model-driven approach to the programmatic instantiation of platform-specific courses. It is perhaps an interesting point of reflection to consider the implications of such model-driven approaches to course deployment in light of the previous paper's cautionary findings regarding the need for personalisation and catering for learning needs.

The article by Wang, Huang, and Quek on the design of blended synchronous learning environments is also timely as we see universities increasingly adopting models of blending cohorts of online and oncampus students. The article highlights the need for technical and pedagogical investment to make such contexts work effectively. Medina's article furthers this conversation by helping to disentangle the language of blended learning by identifying types of 'blends' and their strengths and weaknesses. 
This issue also includes interesting work in the space of professional learning. Lin, Liang, Tsai and Hu report on a study conducted with airline employees in which they found job control, social support and selfregulated learning constituted significant predictors of attitudes towards web-based continuing learning. In a different approach Mirriahi, Jovanovic, Dawson, Gašević and Pardo explore the way in which university educators engage in the use of videos and video annotations in a professional development course. In both papers, there are significant design implications for how we might approach technology enabled professional learning.

This issue also contains two papers that focus on student capacity. Tadesse, Gillies and Campbell offer a new perspective on developing and assessing undergraduate students' integrated information and communication technology (ICT) literacy capacity. Chang, Chou and Liang's paper also focuses on students and investigate the use of ePortfolios to facilitate knowledge sharing and creation among college students.

\section{Acknowledgements}

The production of AJET is a large team effort. The lead editors Associate Professor Eva Heinrich, Associate Professor Michael Henderson, and Associate Professor Petrea Redmond work with a committed team of associate editors who facilitate the reviews and author revisions of papers: Associate Professor Shirley Agostinho; Dr Thomas Donald Cochrane; Dr Linda Corrin; Dr Helen Farley; Associate Professor Paul Gruba; Professor Judi Harris; Dr Chwee Beng Lee; Dr Jason M Lodge; Associate Professor Lina Markauskaite; Dr Stephen Marshall; and Dr Michael Phillips. Backing up the editorial team we have two dedicated copyeditors, Kayleen Wood and Antonina Petrolito who work closely with authors to enhance the quality of the articles by ensuring the text is concise, consistent and accurate. We also need to thank our large number of expert reviewers who ensure our articles are of high standard. And finally, thank you to the authors, who offer valuable new understandings in the field of educational technology; and the readers, without you there would be no AJET.

Eva Heinrich, Michael Henderson \& Petrea Redmond Lead Editors Australasian Journal of Education Technology 